\title{
CEBAKAN NIKEL LATERIT DI PULAU GAG, KABUPATEN RAJA AMPAT, PROVINSI PAPUA BARAT
}

\section{LATERITIC NICKEL DEPOSIT ON GAG ISLAND, RAJA AMPAT REGENCY, WEST PAPUA PROVINCE}

\author{
Sam Permanadewi ${ }^{1}$, Joko Wahyudiono ${ }^{1}$ dan Armin Tampubolon ${ }^{2}$ \\ ${ }^{1}$ Pusat Survei Geologi \\ ${ }^{2}$ Pusat Sumber Daya Mineral, Batubara dan Panas Bumi \\ sam_permanadewi@yahoo.com
}

\begin{abstract}
ABSTRAK
Pulau Gag, yang terletak terpencil di deretan kepulauan Raja Ampat, merupakan pulau yang memendam sumberdaya mineral yang berlimpah. Sumber daya tersebut berupa cebakan bijih nikel laterit $(\mathrm{Ni}, \mathrm{Co}, \mathrm{Fe})$ yang menempati $\pm 2 / 3$ dari pulau tersebut. Secara geologi, 2/3 bagian Pulau Gag ditempati oleh komplek ofiolit yang terdiri atas batuan ultramafik (serpentinit, harzburgit, dan piroksenit) sedangkan sisanya ditempati oleh batuan gunungapi. Komplek ofiolit di Pulau Gag ini diduga sebagai kerak samudera yang secara tektonik tersungkup di tepi benua dan busur kepulauan akibat adanya pergerakan Benua Australia kearah utara. Laterit nikel terbentuk akibat adanya proses pelapukan kimia yang terjadi pada batuan ofiolit yang telah mengandung nikel. Bijih nikel sekunder berupa garnierite diendapkan kembali dalam horizon tanah penutup, limonit dan saprolit setelah mengalami pengayaan oleh proses pelapukan. Berdasarkan hasil analisa contoh, menunjukkan bahwa kandungan $\mathrm{Ni}$ dalam laterit adalah $1,2 \% \mathrm{Ni},>30 \% \mathrm{Fe}$ (lapisan limonit); $1,2 \% \mathrm{Ni},<15 \% \mathrm{Fe}$ (lapisan saprolit).
\end{abstract}

Kata kunci: Ofiolit, Nikel Laterit, Pelapukan Kimia, Kerak Samudera, Pulau Gag

\section{ABSTRACT}

Gag Island, which is separately located from the Raja Ampat Islands, contains mineral resources abundantly. The mineral resource is in the form of lateritic nickel ( $\mathrm{Ni}, \mathrm{Co}, \mathrm{Fe}$ ) occupied approximately 2/3 of the island. Geologically, 2/3 of the Island is occupied by the ophiolite complex contains of ultramafic rocks (serpentinite, harzburgite and pyroxenite) and the rest is volcanic rocks. The emplacement of the ophiolite complex in this island is tectonically emplaced of oceanic crust into continental margin and island arc due to the movement of the Australian Continent to the north. The lateritic nickel was formed due to chemical weathering of the nickel bearing ophiolite rocks. The secondary nickel ore as garnierite was then reprecipited within the lateritic zone as soil cover, limonitic and saprolitic beds. The content of nickel (Ni) within the lateritic zone are 1,2\% $\mathrm{Ni},>30 \% \mathrm{Fe}$ (limonitic layer), $1,2 \% \mathrm{Ni},<15 \% \mathrm{Fe}$ (saprolitic layer).

Keywords: Ophiolite, Lateritic nickel, Chemical weathering, Oceanic crust, Gag Island

\section{PENDAHULUAN}

Pulau Gag, yang merupakan salah satu pulau terpencil di Laut Arafura ini termasuk ke dalam bagian Kabupaten Raja Ampat, Papua Barat (Gambar 1). Pulau yang dihuni oleh pendatang berasal dari Pulau Ternate ini, sebagian besar tersimpan harta karun berupa cebakan nikel laterit yang berlimpah. Nikel laterit berupa garnierit terkonsentrasi dalam batuan ultramafik setelah terjadi pengayaan akibat proses pelapukan. Dua pértiga Pulau Gag merupakan daratan 


\section{MAKALAH ILMIAH}

yang gundul dan hanya ditumbuhi oleh pohon-pohon perdu. Namun, walaupun di atasnya mengalami kekeringan dan tidak memberikan hasil apa-apa, sebaliknya di bawah permukaan pulau ini terdapat bijih laterit nikel (garnierit) yang berlimpah. Berdasarkan hasil evaluasi dari PT. Antam dan BP-Minerals (1999) menunjukkan bahwa jumlah sumber daya bijih nikel dengan kadar $1,55 \%$, termasuk cadangan terbesar ketiga di dunia setelah Goro, Kaledonia Baru.

Berbeda dengan daerah Indonesia bagian barat, nikel laterit yang merupakan hasil pelapukan dari batuan ultramafik banyak ditemukan di Indonesia bagian timur ini. Pulau Gag termasuk pulau-pulau kecil lainnya di bagian utara Pulau Papua merupakan bagian dari Zona Kerak Samudra. Diantaranya adalah Pulau Waigeo yang juga mengandung cebakan nikel laterit bahkan sebagian telah ditambang (Abidin dkk., 2012). Beberapa cebakan nikel laterit yang tidak terdapat di Zona Kerak Samudera telah ditambang sejak lama dan jutaan ton bijih nikel telah diproduksi (Pomala, Sulawesi) (Abidin dan Rahman, 2011), P. Gebe dan Buli, Maba, Halmahera (Maluku Utara) (Abidin dkk., 2007, Abidin dan Baharuddin, 2007). Tentunya, terbentuknya nikel laterit di daerah Indonesia Timur khususnya di Pulau Gag erat kaitannya dengan kondisi geologi serta kondisi cuaca ekstrim sehingga terjadi proses pelapukan yang sangat kuat baik fisik maupun kimia. Pelapukan kimia, diantaranya adalah proses oksidasi yang telah menguraikan mineral nikel dalam batuan terakumulasi dalam zona laterit.

Tulisan ini mencoba untuk mengungkapkan keberadaan nikel laterit di Pulau Gag serta bagaimana proses pembentukan dan hubungannya dengan batuan induk (ofiolit).

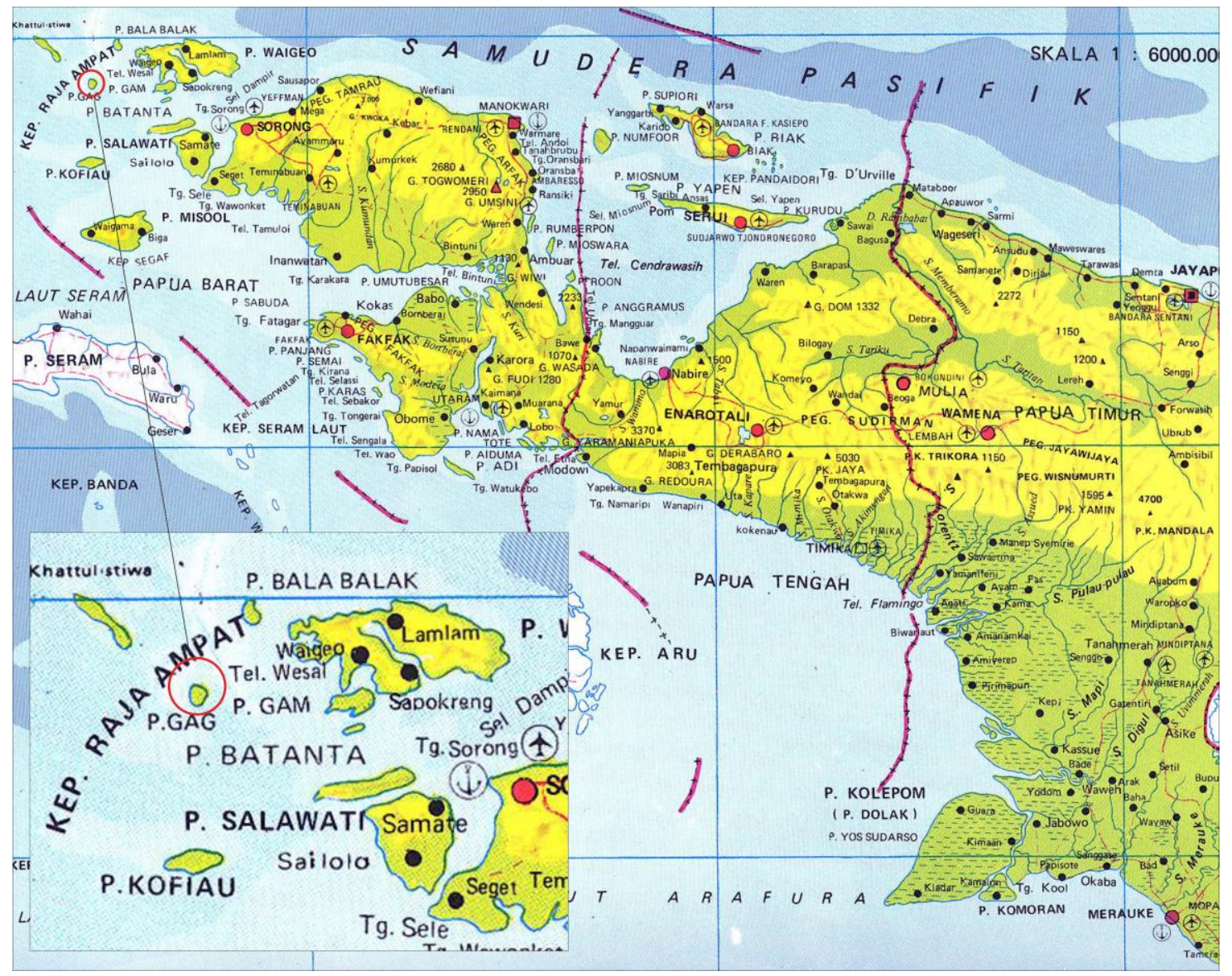

Gambar 1. Peta lokasi daerah penelitian Pulau Gag 


\section{SEJARAH EKSPLORASI}

Eksplorasi nikel laterit di daerah ini telah dilakukan sejak tahun 1967, terakhir oleh PT. Gag Nikel yang mendapatkan Kontrak Karya dari Pemerintah pada bulan Februari 1998. Saat itu Pulau Gag statusnya digolongkan sebagai hutan produksi sehingga secara hukum diperbolehkan untuk melakukan penambangan secara terbuka. Namun pada akhir tahun 1999, Pemerintah Indonesia mengeluarkan kebijakan yang melarang pertambangan terbuka di daerah dengan status "Hutan Lindung". Kebijakan ini kemudian juga diterapkan terhadap Pulau Gag dengan mencabut status sebagian besar lahan hutan produksi menjadi hutan lindung. Padahal kenyatan di lapangan, hutan yang lebat hanya di bagian utara Pulau Gag. Sedangkan di bagian tengah dan selatan $(2 / 3$ bagian dari Pulau Gag) dimana potensi nikel itu terdapat, jarang ditumbuhi vegetasi tinggi.

Sebanyak 75\% saham PT. Gag Nikel dimiliki oleh BHP Asia Pasific Nikel Pty. Ltd. (Australia), sekarang BHP-Billiton, dan 25\% dimiliki oleh PT Aneka Tambang Tbk. Rencananya, di wilayah kerja seluas 7.727 ha ini akan dilakukan penambangan nikel dengan metode Submarine Tailing Disposal (STD). PT. Gag Nikel menghentikan sementara kegiatannya, karena belum mendapatkan jaminan hak secara legal penuh untuk menambang dengan cara pertambangan terbuka seperti yang disebutkan dalam Kontrak Karya. Akhirnya hingga sekarang proses penambangan bijih nikel laterit di Pulau Gag ini terhenti dan sepertinya tidak akan pernah ditambang karena adanya kebijakan baru dari Pemerintah tersebut diatas.

\section{METODA}

Pencontohan dilakukan dalam rangka pengecekan lapangan bersama antara tim geologi dari Pusat Survei Geologi dan tim dari Biro Perencanaan, Kementerian Energi dan Sumber Daya Mineral, pada tahun 1994. Sampel terpilih berupa singkapan batuan ultramafik baik yang segar maupun yang telah mengalami pelapukan kuat, sampel batuan ultramafic untuk diamati di bawah mikroskop. Selain itu, contoh batuan lain (gunung api dan terobosan) juga diambil untuk mempelajari apakah batuan ini ada kaitannya dengan pembentukan mineral lainnya. Analisa petrografi dilakukan di laboratorium Pusat Survei Geologi. Sedangkan PT. AntamBHP melaksanakan analisa kimia untuk sampel laterit dan hasilnya dapat dilihat di Tabel 1.

\section{GEOLOGI}

\section{Fisiografi dan Geomorfologi}

Secara fisiografi, Pulau Gag yang terletak terisolasi di Laut Halmahera, termasuk ke dalam Zona Kerak Samudera (Gambar 2). Daerah ini merupakan pusat gempa bumi Halmahera-Irian. Kerak samudera yang tersingkap adalah batuan ofiolit yang berumur Jura (Kertapati dkk., 2001). Pulau Gag berbentuk opal dengan luas wilayah sekitar 14,5x8 $\mathrm{km}^{2}$. Elevasi maksimum sekitar $350 \mathrm{~m}$ dpl.

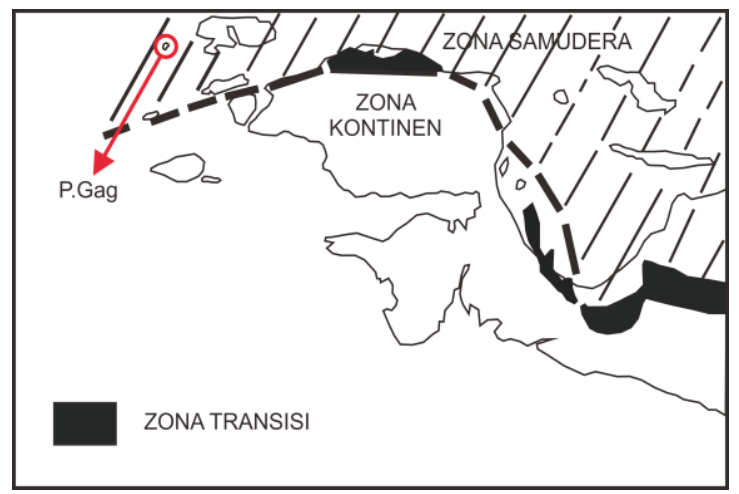

Gambar 2. Fisiografi Pulau Gag

(Pieters dkk., 1983)

Geomorfologi Pulau Gag memperlihatkan 3 jenis bentang alam, yaitu satuan perbukitan bergelombang curam, satuan perbukitan bergelombang landai dan satuan dataran (Gambar 3). Satuan perbukitan bergelombang dengan kemiringan curam menempati 2/3 bagian Pulau Gag, yaitu dari bagian tengah sampai ke selatan dari Pulau Gag dengan 


\section{MAKALAH ILMIAH}

ketinggian berkisar dari 200 s.d. $350 \mathrm{~m}$ di atas permukaan laut (Gambar 4 ).

Pada umumnya satuan ini bercirikan jarangnya vegetasi tinggi yang tumbuh dan tebal tanah penutup/pelapukan yang tipis. Di beberapa tempat bahkan tidak dijumpai adanya vegetasi kecuali rerumputan, alang-alang dan tumbuhan kerdil jenis pepohonan perdu (Gambar 5.a-b). Sulitnya pepohonan tumbuh di daerah terbuka ini disebabkan tanah penutup/soil berupa laterit yang kaya akan bijih nikel dan besi.

Satuan perbukitan bergelombang landai (Gambar 3 dan Gambar 4) menempati 1/3 bagian utara Pulau Gag. Satuan ini dicirikan dengan banyaknya vegetasi tinggi hutan hujan tropis (Gambar 5.c). Hal ini menunjukkan tebalnya lapisan tanah penutup yang cukup tebal dan subur karena merupakan produk dari gunung api. Kondisi tanah yang subur ini sebagian dimanfaatkan masyarakat setempat untuk berkebun kelapa dan coklat. Batuan penyusun satuan morfologi ini terdiri dari satuan anggota batuan gunungapi seperti lava, breksi, tuff lava dan andesit.
Satuan morfologi dataran dibentuk oleh endapan aluvial (Gambar 5.d). Satuan ini menempati wilayah pantai bagian utara dan Teluk Gambir, sebagian kecil pantai selatan Pulau Gag, khususnya muara sungai dan lembah-lembah di sekitar pantai. Endapan aluvial ini berupa pasir, kerikil, kerakal dan koral (Gambar 5e). Daerah ini banyak dimanfaatkan oleh penduduk setempat untuk berkebun kelapa, dan di beberapa tempat khususnya yang dekat dengan dengan muara dan aliran sungai banyak ditemukan pohon sagu.

Pulau Gag ini dialiri oleh sungai-sungai yang terletak di bagian utara yaitu Sungai Musowalo dan Sungai Gambir. Kedua sungai ini selalu berair sepanjang tahun dengan sumber air berasal dari rembesanrembesan air di zona sesar. Sedangkan sungai-sungai yang lain yaitu yang terletak di bagian selatan pada umumnya memiliki dinding yang terjal dan hanya berair di musim hujan. Sepanjang pantai bagian utara kearah timur hingga selatan masih banyak ditemukan terumbu koral. Hal ini menunjukkan bahwa kualitas air di sepanjang pantai tersebut masih bagus atau belum tercemar.

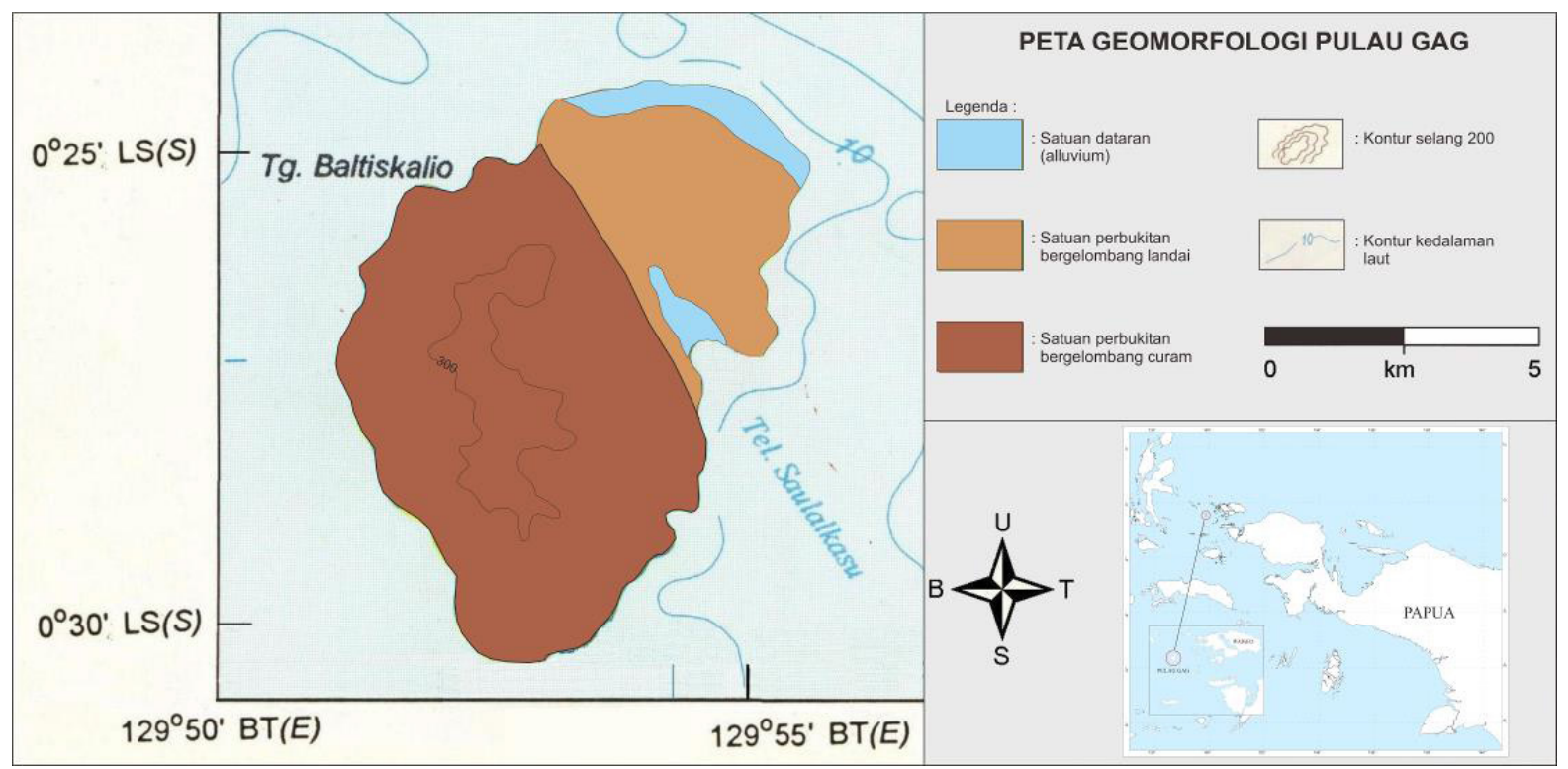

Gambar 3. Peta geomorfologi Pulau Gag (Supriatna dkk., 1995) 


\section{MAKALAH ILMIAH}

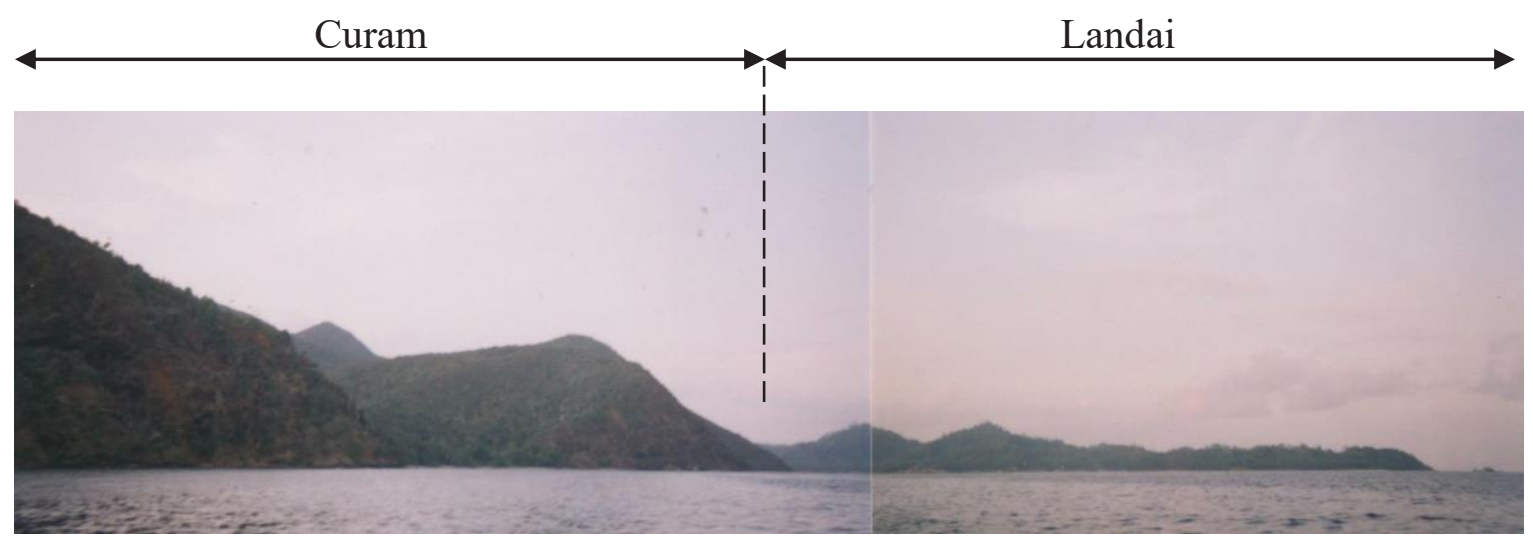

Gambar 4. Memperlihatkan kenampakan di lapangan satuan perbukitan bergelombang dengan kemiringan curam dan landai

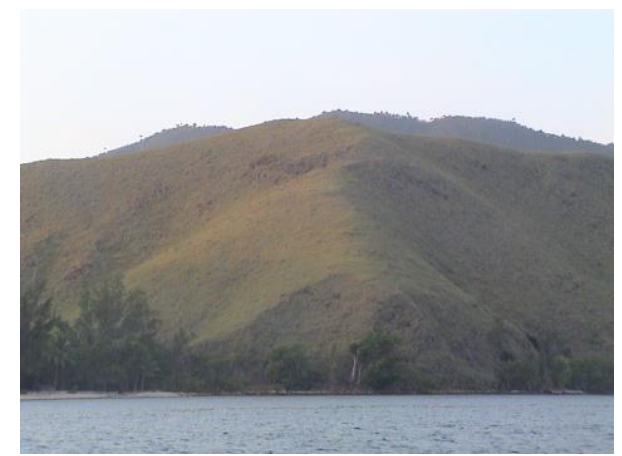

(a)

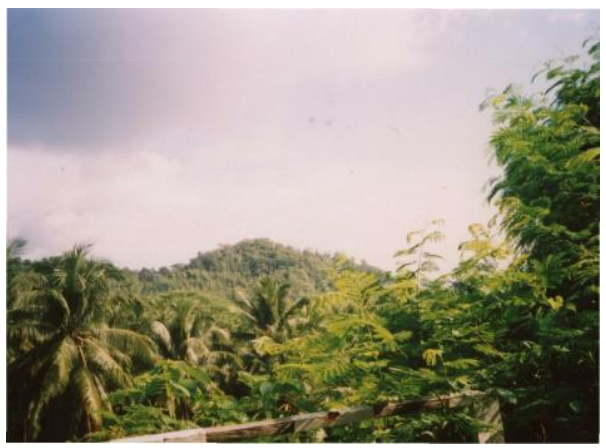

(c)

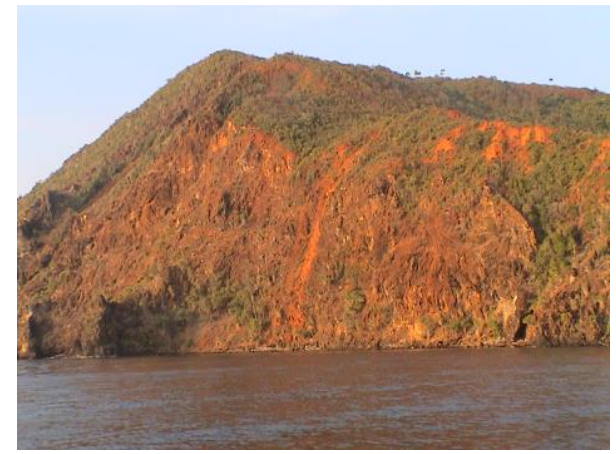

(b)

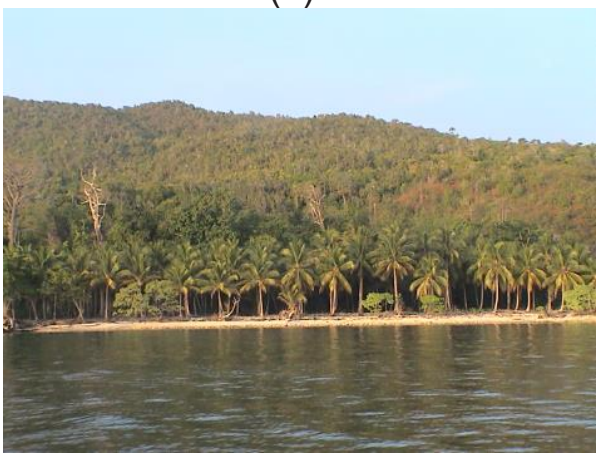

(d)

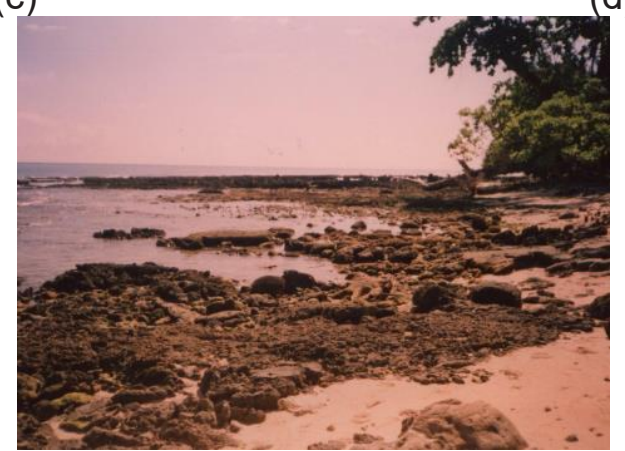

(e)

Gambar 5. (a) perbukitan tanpa vegetasi; (b) dinding terjal di pantai barat;

(c) vegetasi yang tumbuh di perbukitan bergelombang landai;

(d) morfologi dataran aluvial dengan latar belakang perbukitan vegetasi jarang; (e) endapan aluvial yang ditutupi koral 


\section{STRATIGRAFI}

Berdasarkan peta geologi bersistem Indonesia skala 1:250.000, Pulau Gag masuk ke dalam peta geologi lembar Waigeo (Supriatna dkk., 1995). Secara geologi, daerah ini sangat sederhana (Gambar 6). Batuan tertua yang tersingkap di daerah ini adalah batuan ultramafik. Batuan ini terdiri dari harzburgit, dunit, piroxenit, diabas dan serpentinit. Namun di lapangan, batuan yang umum dijumpai adalah serpentinit dan harzburgit. Serpentinit berwarna abu kehijauan, kehitaman, keras, padat, kompak, fractured, terkekarkan, tergeruskan; umumnya lapuk (Gambar 7ab). Di beberapa tempat, dijumpai zona gerusan mengandung magnesit, milonit dan urat kuarsa, sedangkan dalam batuan yang lapuk berupa laterit dijumpai mineral nikel sebagai garnierit. Batuan ini tersingkap di bagian selatan Pulau Gag.

Secara kontak sesar, batuan ultramafik ditindih oleh anggota batuan gunungapi Formasi Rumai, yang terdiri dari lava, breksi, tuf lava dan batugamping. Batuanbatuan ini tampaknya telah diterobos oleh retas-retas batuan subvulkanik sehingga sebagian telah mengalami ubahan serta munculnya urat-urat kuarsa. Endapan termuda berupa kerikil, kerakal, pasir, lempung dan koral.

Anggota batuan gunungapi Formasi Rumai terdiri atas lava bantal, breksi, tuf, batugamping dan andesit. Batuan ini menempati $\pm 1 / 3$ bagian dari Pulau Gag (Gambar 6). Batugamping berwarna abuabu kotor, konglomeratan, berlapis tebal hingga massif (Gambar 8a). Tuf, berwarna putih kotor, berbutir halus, pada umumnya, telah mengalami pelapukan kuat dan menutupi lava (Gambar 8b). Batuan ini tersingkap di desa Gambir. Lava basal, berwarna hitam kelabu, agak keras dan padat, kekaran, berstruktur bantal, sebagian lapuk dan telah mengalami ubahan. Hasil pengamatan petrografi menunjukkan bahwa lava telah terubah cukup kuat dengan munculnya mineral klorit, serisit, epidot, kalsit dan mineral opak (Gambar 8c-d). Mineral utama penyusun batuan ini umumnya berupa feldspar namun telah mengalami ubahan kuat. Andesit, berwarna kelabu, keras dan agak padat serta tersingkap di sepanjang jalan ke pelabuhan udara (Kablebet). Seperti halnya lava, andesit juga telah mengalami ubahan dengan munculnya mineral klorit, serisit, epidot dan kalsit (Gambar 8e-f). Breksi gunungapi, berwarna abu-abu, keras dan padat, komponen yang menyudut hingga menyudut tanggung, terdiri dari batuan gunungapi dengan ukuran berkisar dari 1$4 \mathrm{~cm}$ tertanam dalam masa dasar pasiran. Breksi ini banyak tersingkap di bagian utara Pulau Gag (Gambar 8g). Anggota batuan gunungapi Rumai ini diendapkan secara selaras di atas Formasi Lamlam dengan ketebalan lebih kurang $450 \mathrm{~m}$.

Endapan aluvial terdiri dari Kerakal, kerikil, pasir, lanau, lumpur, sisa tumbuhan dan koral. Sebarannya dijumpai di daerah pantai, sungai-sungai kecil dan dataran rendah. Di pantai bagian utara dan timur Pulau Gag dijumpai endapan koral yang cukup luas. Selain itu, endapan aluvium juga dijumpai membentuk dataran pada lembah-lembah di daerah pantai bagian selatan dan barat.

\section{Struktur Geologi}

Secara umum, Pulau Gag diapit oleh Sesar Sorong dan Sesar Halmahera (Gambar 9) dan membentuk kelurusan arah barat laut-tenggara. Kelurusan ini membentang ke arah barat laut menuju kearah Pulau Gebe yang sejajar dengan bentuk teluk Saulalkasu. Kelurusan tersebut diperkirakan berhubungan dengan sesar yang berkembang di daerah tersebut.

Pulau Gag masuk ke dalam peta geologi lembar Waigeo, secara umum sejarah ketektonikannya sangat terkait dengan tektonik regional daerah itu. Pada Akhir Jura, terjadi pemekaran Samudra Pasifik. Pemekaran tersebut diikuti oleh pembentukan laut dalam yang mengakumulasikan endapan laut dalam 
Formasi Tanjung Bomas. Selama proses itu berlanjut, banyak sesar geser terbentuk sehingga mengakibatkan pelengseran. Selanjutnya, kurang lebih berakhir pada Awal Tersier terjadi pengendapan Formasi Lamlam.

Pada akhir Kapur, Benua Australia bergerak ke arah utara dan membentuk busur kepulauan yang beralaskan batuan ofiolit hasil penunjaman supra. Pada kegiatan ini terjadi pengendapan Formasi Rumai yang sebagian terbentuk di bawah permukaan air dan kegiatan itu mencapai puncaknya antara Eosen dan Miosen. Setelah busur kepulauan terbentuk, mulai Miosen Awal hingga Miosen Akhir terjadi pengendapan Formasi Waigeo di sekitar kepulauan itu. Bersamaan dengan pengendapan Formasi Waigeo, selama Miosen hingga Pliosen, diikuti pula pengikisan sehingga terbentuklah batugamping klastika Formasi Puri.

Formasi Yeben mengandung kuarsa diduga berasal dari benua Australia.
Pembentukan satuan itu diduga mengelilingi kawasan batugamping di bagian baratdaya kepulauan tersebut. Pengangkatan yang terjadi di pulau tersebut diikuti oleh pengikisan yang hasilnya membentuk endapan alluvium dan tumbuhnya terumbu karang di beberapa tempat.

Di lapangan, indikasi adanya sesar ditunjukkan dengan adanya zona hancuran selebar $\pm 50 \mathrm{~m}$ berupa breksi sesar yang terletak di dekat Teluk Gambir tepatnya pada perbatasan antara satuan morfologi perbukitan bergelombang curam dan perbukitan bergelombang landai, dan membentuk kelurusan arah tenggara barat laut (Gambar 9). Bidang sesar ini sebagai pemisah antara satuan batuan ultramafik dengan satuan anggota batuan gunungapi dan telah mengangkat batuan ultramafik ke permukaan dengan posisi sejajar dengan anggota batuan gunungapi.

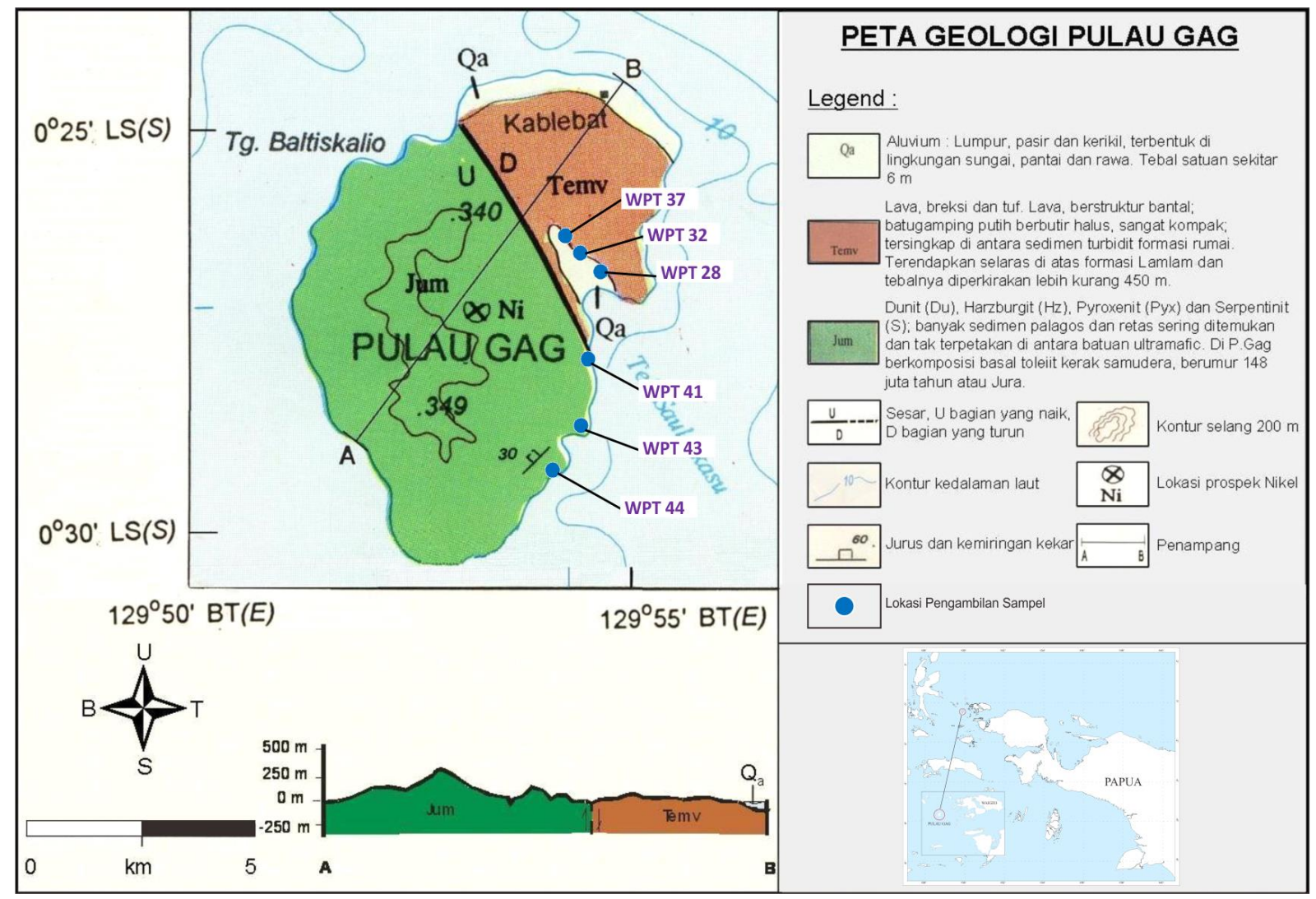

Gambar 6. Peta geologi Pulau Gag (Supriatna dkk., 1995) 


\section{MAKALAH ILMIAH}

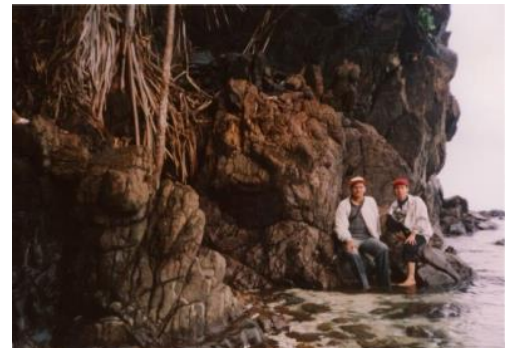

(a)

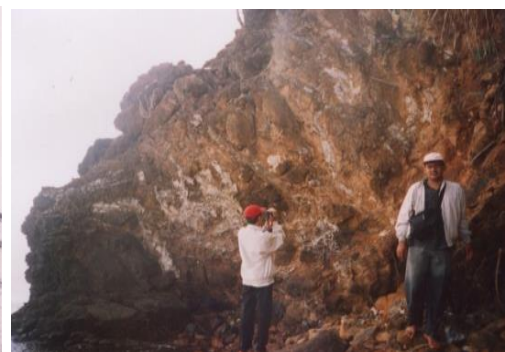

(b)

Gambar 7. (a) Singkapan batuan harzburgit di pantai selatan Pulau Gag

(b) Singkapan batuan hazburgit terubah di bagian selatan Pulau Gag.

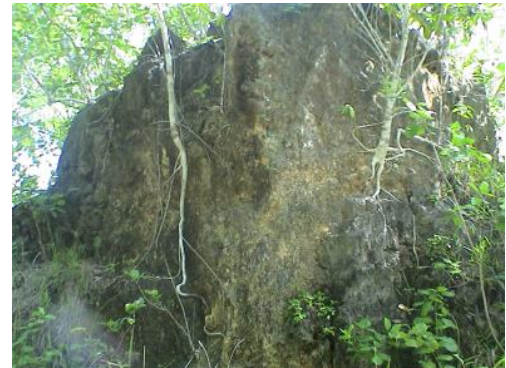

(a)

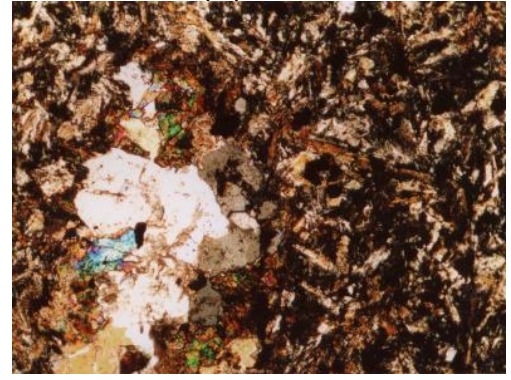

(c)

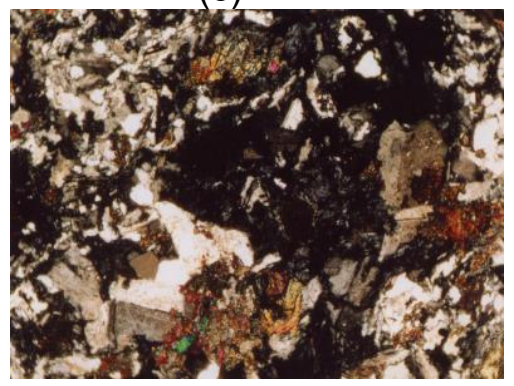

(e)

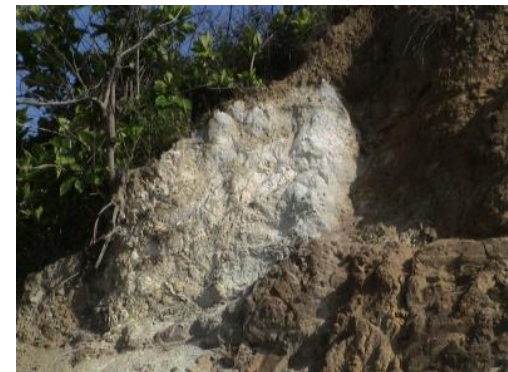

(b)

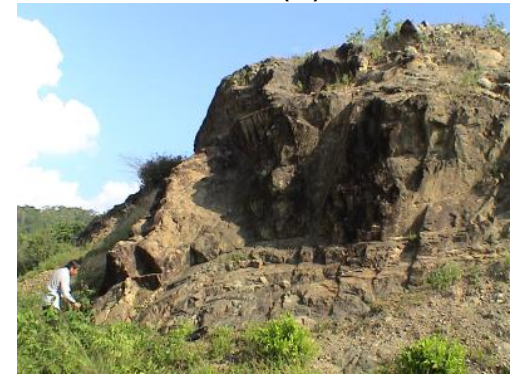

(d)

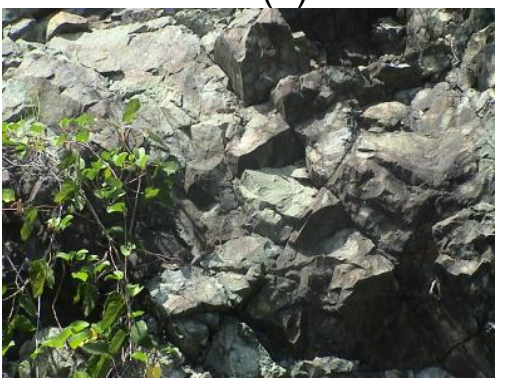

(f)

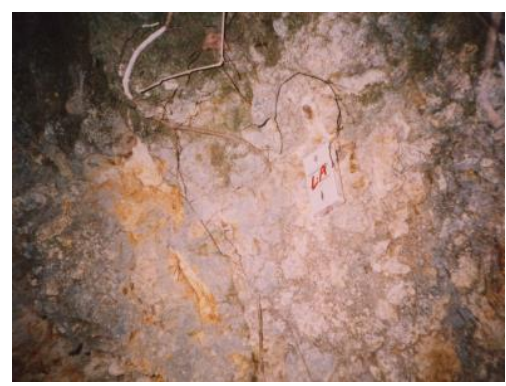

(g)

Gambar 8. (a) Batu gamping klastik; (b) tuf ;(c) sayatan pipih lava basal; (d) singkapan lava basal (WPT 28); (e) sayatan pipih andesit; (f) singkapan andesit (WPT 37); (g) breksi gunungapi (WPT 32). 


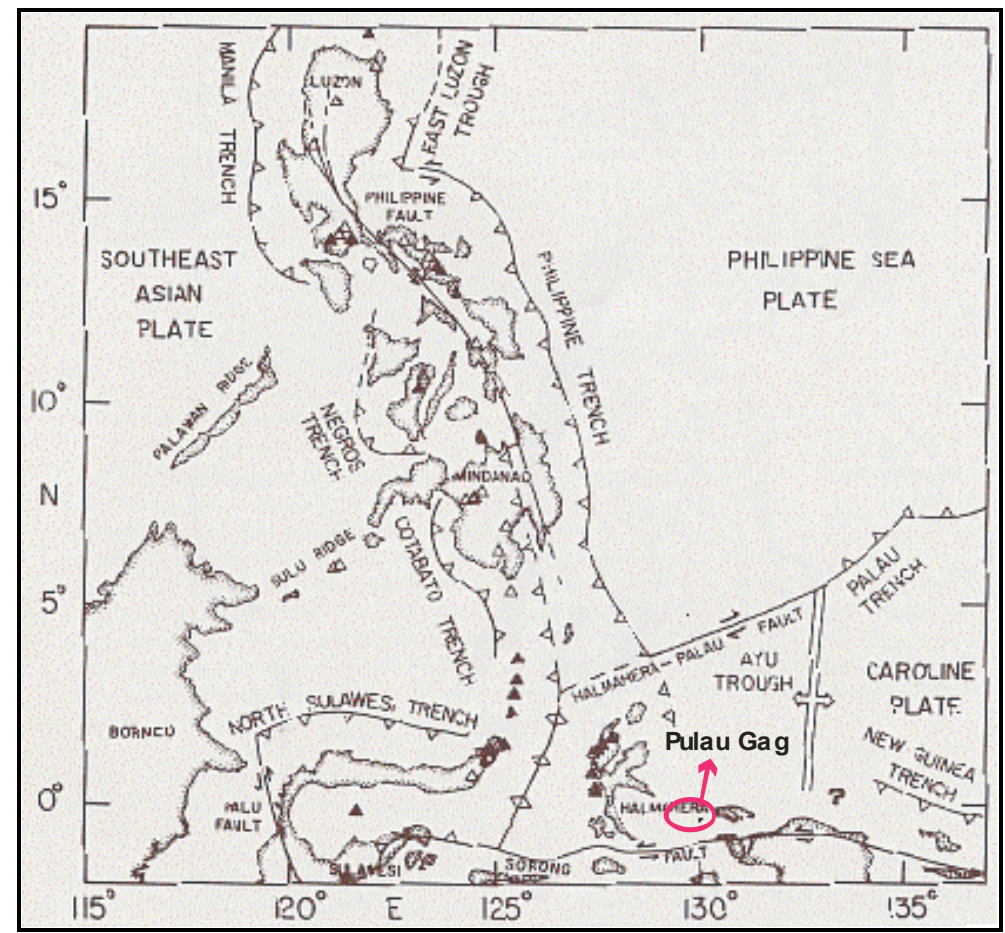

Gambar 9. Peta tektonik timurlaut Indonesia dan Filipina dimana Pulau Gag diapit oleh Sesar Sorong dan Sesar Halmahera-Papua (Hamilton, 1979, dalam Supriatna, dkk., 1995)

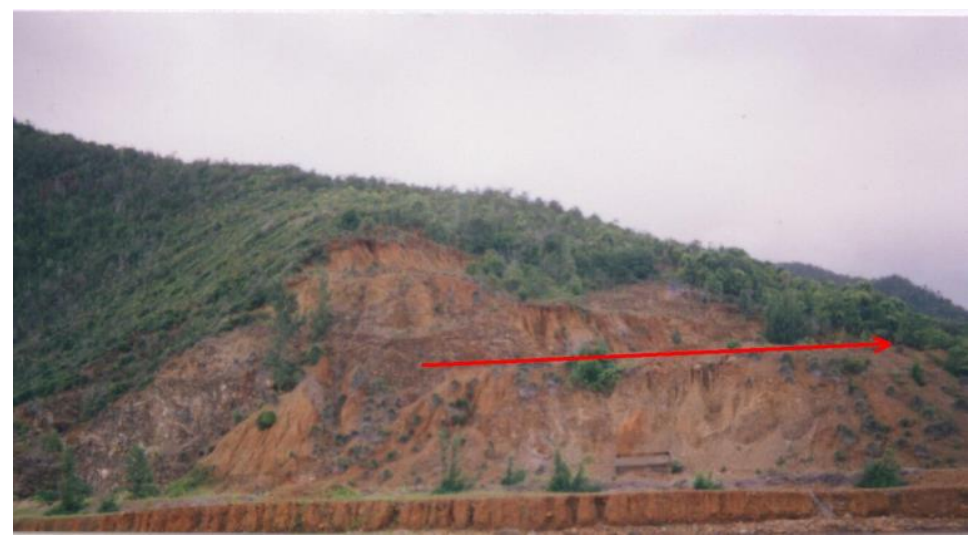

Gambar 10. Singkapan yang memperlihatkan zona hancuran dan kelurusan arah sesar (anak panah).

\section{Mineralisasi}

Potensi sumberdaya mineral logam yang dijumpai adalah endapan nikel laterit. Keberadaan nikel di daerah ini sesuai dengan kondisi geologi di mana batuan induknya berupa batuan ultramafik. Selain itu, dijumpai adanya jejak pirit dalam batuan gunungapi Rumbai.

Cebakan lateritic nicke/ Ni-Co berkembang ke arah bagian selatan meliputi $2 / 3$ pulau. Cebakan ini merupakan hasil proses oksidasi/leaching dari serpentinit. Batuan ini diduga berasal dari magma cair pada kedalaman yang sangat dalam dan membawa Ni-Co. Komposisi batuan peridotit yang terserpentinasi diduga mengandung $80 \% \mathrm{Si}, \mathrm{Mg}, 7 \%$ s.d. $10 \%$ $\mathrm{Fe}, 0,2$ s.d $0.3 \% \mathrm{Ni}$ dan $0,01 \%$ Co. $\mathrm{Di}$ dalam kondisi oksidasi, mineral dalam batuan induk terurai membebaskan $\mathrm{Ni}$ dan $\mathrm{Mg}$ dan bercampur dengan larutan air tanah. Konsentrasi kadar bijih yang potensial dari $\mathrm{Ni}$ terdapat dalam zona limonit dan zona saprolit berupa mineral garnierit $\quad\left(\mathrm{H}_{2} \mathrm{O} \quad\left(\mathrm{Mg}, \mathrm{Ni}_{3} \mathrm{Sllll}_{4} \mathrm{O}_{10} \quad \mathrm{OH}\right)\right.$ (Gambar 11a,b). 


\section{MAKALAH ILMIAH}

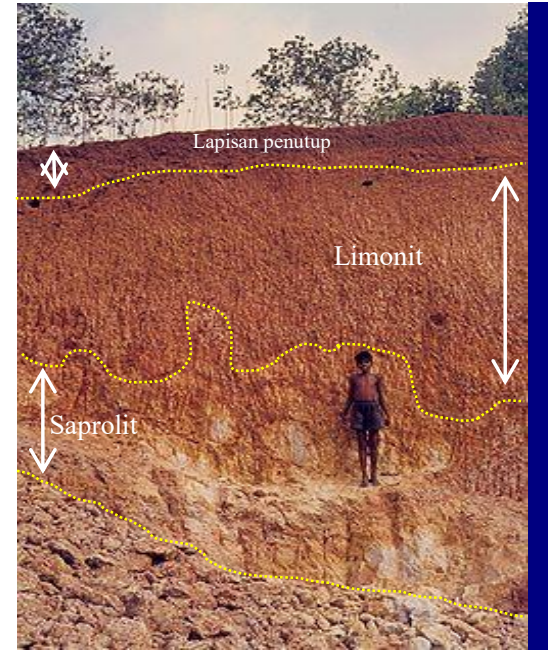

(a)

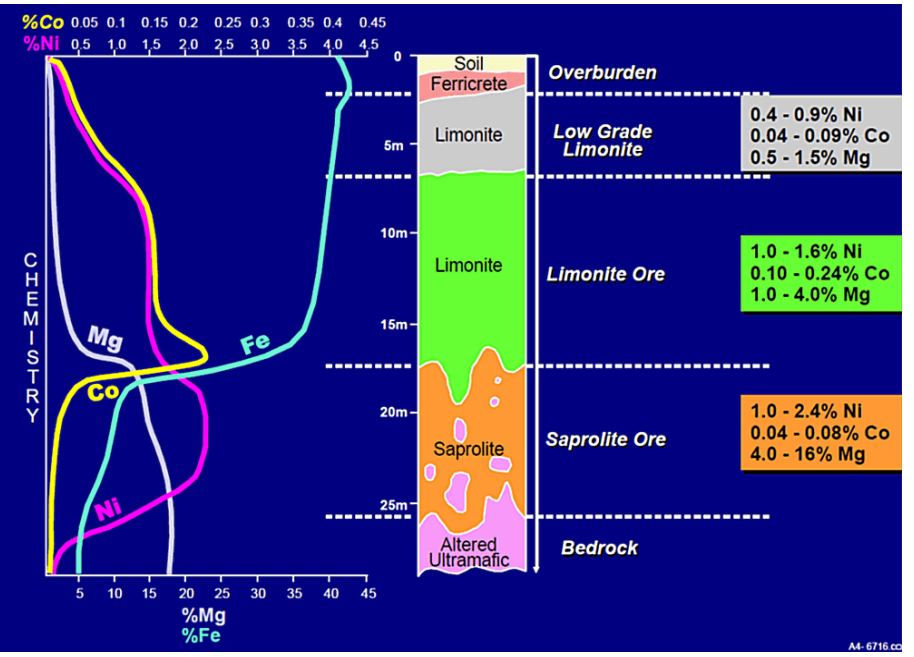

(b)

Gambar 11. (a) Singkapan penampang vertikal laterit

yang memperlihatkan lapisan penutup, lapisan limonit dan lapisan saprolit.

(b) Konsentrasi kadar bijih yang potensial dari Ni terdapat dalam zona limonit, zona saprolit

(Geoscience \& Natural Resources, Germany, 1982)

\section{HASIL}

\section{Petrologi}

Beberapa contoh terpilih telah dilakukan pengamatan petrografi guna mengetahui komposisi dan tekstur batuan. Dari pengamatan petrografi menyimpulkan bahwa batuan ultramafik di daerah ini termasuk harzburgit/serpentinit. Harzburgite memperlihatkan tekstur holokristalin dengan mineral penyusun utama berupa piroksen dan olivin (Gambar 12a). Mineral-mineral penyusun ini telah mengalami tektonik sehingga terhancurkan dan memperlihatkan adanya struktur mesh (Gambar 12b-c). Pada bidang rekahan/belahan umum diisi oleh serpentin (Gambar 12d-e), magnesit atau urat kuarsa. Serpentinit umumnya telah mengalami pelapukan kuat sehingga sulit untuk mendapatkan contoh yang segar.

Diabas berwarna abu kehitaman, keras, padat, fractured, kekaran, terubah dan banyak ditemukan urat kuarsa tipis. Hasil pengamatan petrografi menunjukkan bahwa batuan ini telah mengalami ubahan cukup kuat namun tekstur diabasik masih dapat diamati (Gambar 13 a-b). Dalam batuan ultramafik sering dijumpai retas batuan subvolkanik andesit. Diduga bahwa retas-retas inilah yang menyebabkan terubahnya baik batuan ultramafik maupun batuan gunungapi.

\section{Analisa contoh}

Contoh diambil dari zona laterit secara vertikal termasuk lapisan tanah penutup hingga ke batuan dasar (basement). Lapisan laterit secara vertikal dikenal dengan tanah penutup, limonit dan saprolit (Gambar 11). Kedalaman pengambilan contoh bervariasi dari 0 s.d. $5 \mathrm{~m}, 0$ s.d. $6 \mathrm{~m}$ dan 0 s.d. 7 m (Gambar 14). Hasil analisa beberapa penampang terpilih, menunjukkan bahwa kandungan nikel juga bervariasi. Hasil analisis kandungan logam setiap penampang terlihat dalam Tabel 1. Pada umumnya, kandungan $\mathrm{Ni}$ relatif meningkat dengan kedalaman; kandungan kobal (Co) umumnya menurun sejalan dengan kedalaman sedangkan kandungan $\mathrm{Fe}$ memperlihatkan sedikit perubahan dengan kedalaman bahkan relatif konstan. 


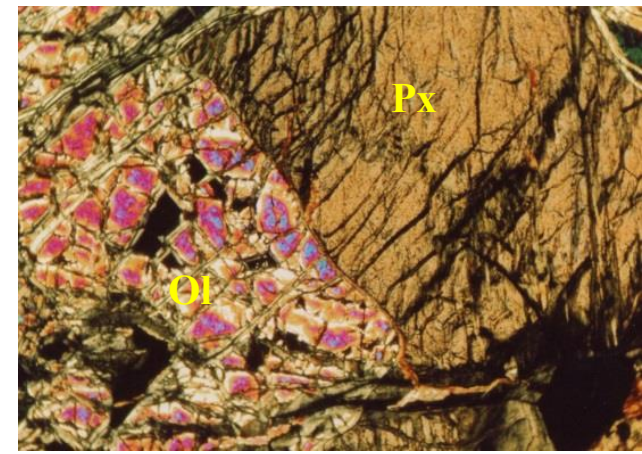

(a)

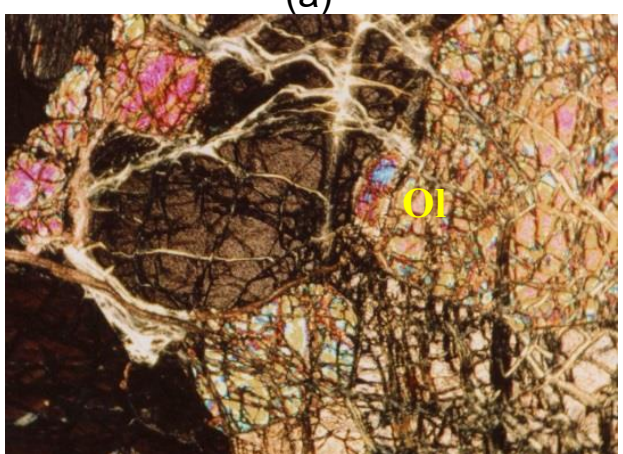

(c)

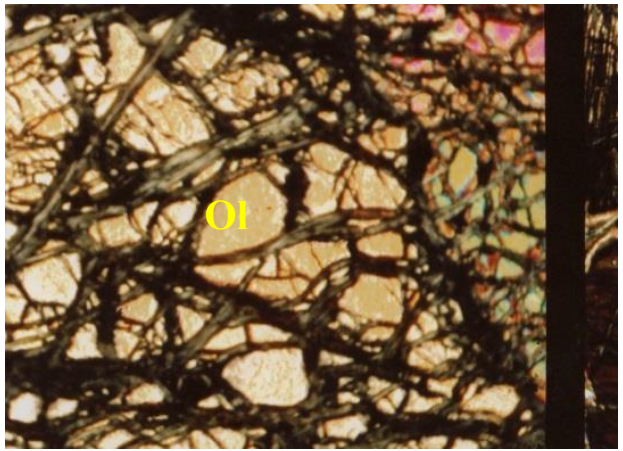

(b)

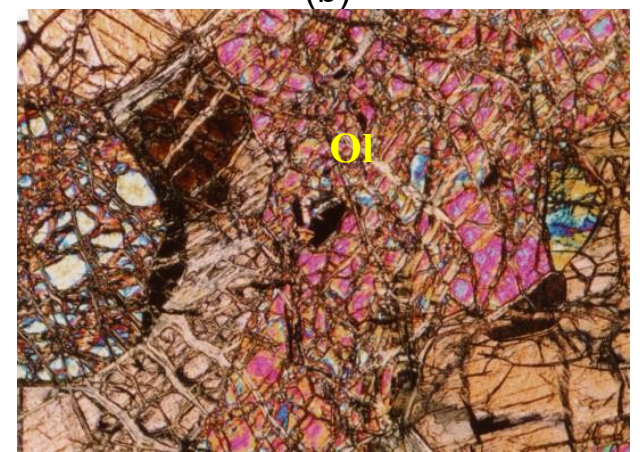

(d)

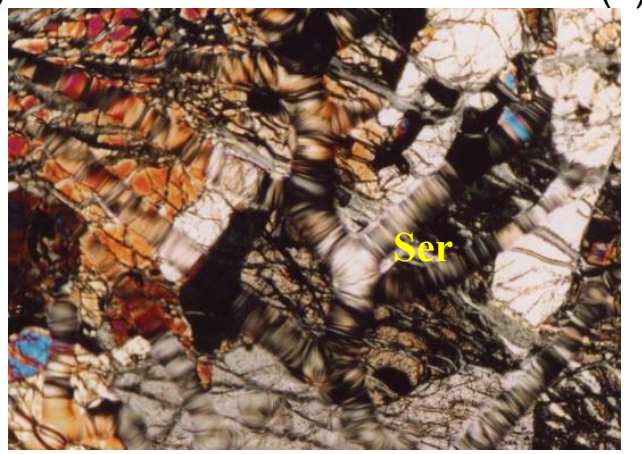

(e)

Gambar 12. Foto mikroskopik (perbesaran $4 \mathrm{x}$ ) batuan harzburgit.

(a). memperlihatkan mineral penyusun harzburgit : piroksen dan olivin;

(b) harzburgit tekstur pulau; (c, d) harzburgit memperlihtakan tekstur mesh

(e) tampak urat-urat serpentin saling berpotongan

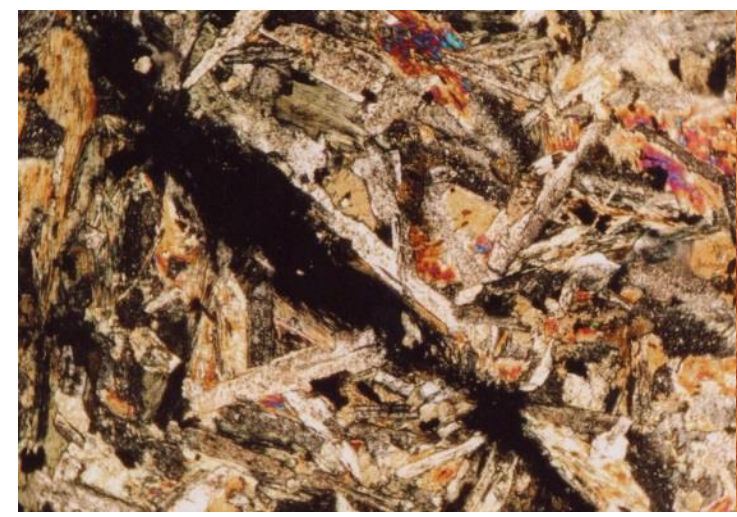

(a)

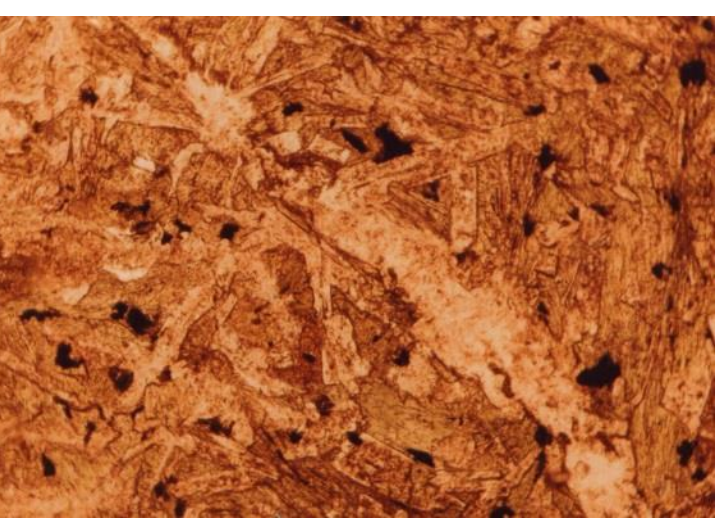

(b)

Gambar 13. Mikrofoto diabas terubah memperlihatkan tekstur diabasik

(a). X-nikol (nikol bersilang), (b). //-nikol (nikol sejajar) 


\section{MAKALAH ILMIAH}

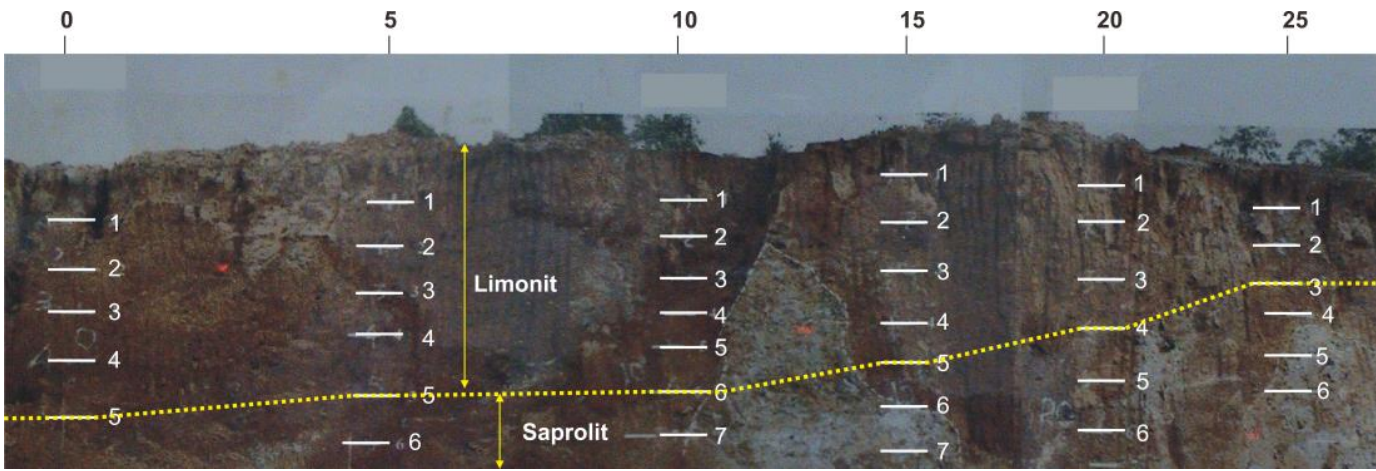

Gambar 14. Penampang ketebalan laterit dan kandungan logamnya

(sumber: Pit 3 - West Wall, BHP Asia Pasific Nickel, 1997)

Tabel 1. Hasil analisa (\%) contoh untuk penampang terpilih pada salah satu singkapan laterit di Pulau Gag (Sumber data: PT Antam-BHP, 1999)

\begin{tabular}{|c|c|c|c|c|c|c|}
\hline Section & From & To & $\mathrm{Ni}$ & Co & Mg & $\mathrm{Fe}$ \\
\hline \multirow[t]{5}{*}{0} & 0.0 & 1.0 & 1.30 & 0.24 & 0.23 & 45.90 \\
\hline & 1.0 & 2.0 & 1.45 & 0.20 & 0.23 & 50.00 \\
\hline & 2.0 & 3.0 & 1.51 & 0.12 & 0.25 & 50.80 \\
\hline & 3.0 & 4.0 & 1.26 & 0.02 & 0.27 & 56.40 \\
\hline & 4.0 & 5.0 & 1.43 & 0.19 & 0.50 & 50.60 \\
\hline \multirow[t]{6}{*}{5} & 0.0 & 1.0 & 1.51 & 0.30 & 0.17 & 47.80 \\
\hline & 1.0 & 2.0 & 1.60 & 0.23 & 0.21 & 50.40 \\
\hline & 2.0 & 3.0 & 1.59 & 0.15 & 0.16 & 50.10 \\
\hline & 3.0 & 4.0 & 1.63 & 0.17 & 0.22 & 53.20 \\
\hline & 4.0 & 5.0 & 1.45 & 0.13 & 0.51 & 51.50 \\
\hline & 5.0 & 6.0 & 1.50 & 0.23 & 0.35 & 43.70 \\
\hline
\end{tabular}

\begin{tabular}{|c|r|r|r|c|c|c|}
\hline Section & From & \multicolumn{1}{c|}{ To } & \multicolumn{1}{l|}{$\mathbf{~ N i}$} & Co & Mg & Fe \\
\hline 10 & 0.0 & 1.0 & 1.51 & 0.13 & 0.18 & 51.90 \\
\hline & 1.0 & 2.0 & 1.50 & 0.11 & 0.22 & 52.40 \\
\hline & 2.0 & 3.0 & 1.57 & 0.13 & 0.25 & 53.70 \\
\hline & 3.0 & 4.0 & 1.30 & 0.16 & 0.25 & 45.50 \\
\hline & 4.0 & 5.0 & 1.52 & 0.21 & 0.43 & 49.30 \\
\hline & 5.0 & 6.0 & 1.47 & 0.22 & 0.30 & 49.60 \\
\hline & 6.0 & 7.0 & 1.54 & 0.13 & 2.20 & 42.20 \\
\hline & 7.0 & 8.0 & 1.93 & 0.09 & 6.54 & 28.60 \\
\hline \multicolumn{7}{|c|}{} \\
\hline 15 & 0.0 & 1.0 & 1.32 & 0.07 & 0.34 & 48.20 \\
\hline & 1.0 & 2.0 & 1.31 & 0.12 & 0.25 & 51.60 \\
\hline & 2.0 & 3.0 & 1.21 & 0.19 & 0.29 & 43.30 \\
\hline & 3.0 & 4.0 & 1.26 & 0.15 & 1.01 & 40.80 \\
\hline & 4.0 & 5.0 & 1.86 & 0.22 & 0.71 & 49.80 \\
\hline & 5.0 & 6.0 & 2.07 & 0.14 & 3.93 & 38.70 \\
\hline & 6.0 & 7.0 & 2.35 & 0.02 & 14.30 & 10.70 \\
\hline
\end{tabular}

\begin{tabular}{|l|r|r|r|c|c|c|}
\hline Section & From & \multicolumn{1}{|c|}{ To } & Ni & Co & Mg & Fe \\
\hline 20 & 0.0 & 1.0 & 1.23 & 0.13 & 0.28 & 47.20 \\
\hline & 1.0 & 2.0 & 1.24 & 0.07 & 0.30 & 46.30 \\
\hline & 2.0 & 3.0 & 1.07 & 0.07 & 0.30 & 43.70 \\
\hline & 3.0 & 4.0 & 1.82 & 0.48 & 0.27 & 44.30 \\
\hline & 4.0 & 5.0 & 1.56 & 0.13 & 0.26 & 48.40 \\
\hline & 5.0 & 6.0 & 1.57 & 0.11 & 0.23 & 47.50 \\
\hline & 6.0 & 7.0 & 1.31 & 0.09 & 0.16 & 48.60 \\
\hline \multicolumn{7}{|c|}{} \\
\hline 25 & 0.0 & 1.0 & 1.15 & 0.12 & 0.23 & 44.80 \\
\hline & 1.0 & 2.0 & 1.12 & 0.13 & 0.30 & 43.00 \\
\hline & 2.0 & 3.0 & 1.24 & 0.40 & 0.26 & 42.10 \\
\hline & 3.0 & 4.0 & 1.51 & 0.17 & 0.85 & 48.10 \\
\hline & 4.0 & 5.0 & 2.10 & 0.07 & 7.16 & 27.50 \\
\hline & 5.0 & 6.0 & 1.79 & 0.02 & 12.10 & 13.20 \\
\hline & 6.0 & 7.0 & 2.62 & 0.03 & 11.50 & 18.70 \\
\hline & 7.0 & 8.0 & 2.22 & 0.02 & 12.30 & 13.90 \\
\hline
\end{tabular}

\section{Batuan Sumber}

Batuan ultramafik yang dikenal sebagai komplek ofiolit, merupakan suatu runtunan batuan basa sampai ultrabasa (Gambar 15). Kelompok ofiolit ini disusun oleh peridotit (Iherzolit, harzburgit, wehrlit dunit) dan piroksenit (olivin websterlit, olivin othopiroksenit, olivin klinopiroksenit, dan websterlit) (Wilson, 1989). Ofiolit dapat pula dinyatakan sebagai bagian litosfer samudera yang secara tektonik muncul sebagai massa tersungkup di tepi kontinen dan busur kepulauan. Seperti terlihat dalam Gambar 15, runtunan ofiolit dapat dibagi ke dalam 4 lapisan atau delapan lapisan.

Logam yang dijumpai dalam runtunan batuan ofiolit terutama kromit $(\mathrm{Cr})$ yang terbentuk pada lapisan ultrabasa; emas $(\mathrm{Au})$, tembaga $(\mathrm{Cu})$, Nikel $(\mathrm{Ni})$ dan kobal (Co) terdapat pada lapisan batuan gabrodiorit; sedangkan perak $(\mathrm{Ag})$, pirit dan seng $(\mathrm{Zn})$ terbentuk di dalam lapisan batuan gunungapi (Edward dan Atkinson, 1986; Evan, 1992). Selain mineralisasi primer, di dalam batuan ofiolit terjadi pula mineralisasi sekunder seperti magnesit, talk, asbes, laterit, antigorit, nikel dan laterit.

Nicolas (1989) mengelompokkan dua tipe batuan ofiolit, yaitu Harzburgit Ophiolite Type (HOT) dan Lherzolite Ophiolite Type (LOT). Dalam batuan HOT terdapat mineralisasi kromit dalam bentuk stratiform maupun pediform sedangkan dalam LOT tidak dijumpai adanya mineralisasi.

Di daerah penelitian, secara mikroskopis batuan ofiolit terdiri atas harzburgit yang mendominasi seluruh batuan yang ada. Namun, batuan lainnya seperti serpentinit, dunit, piroksenit juga terdapat dalam komplek ofiolit di Pulau Gag ini. Seperti telah dibahas sebelumnya bahwa penyusun batuan harzburgit terutama mineral ortopiroksen dan olivin. Batuan serpentinit di Pulau Gag, umumnya telah mengalami pelapukan kuat serta proses alterasi sehingga terbentuk mineral serpentin dan asbes. 


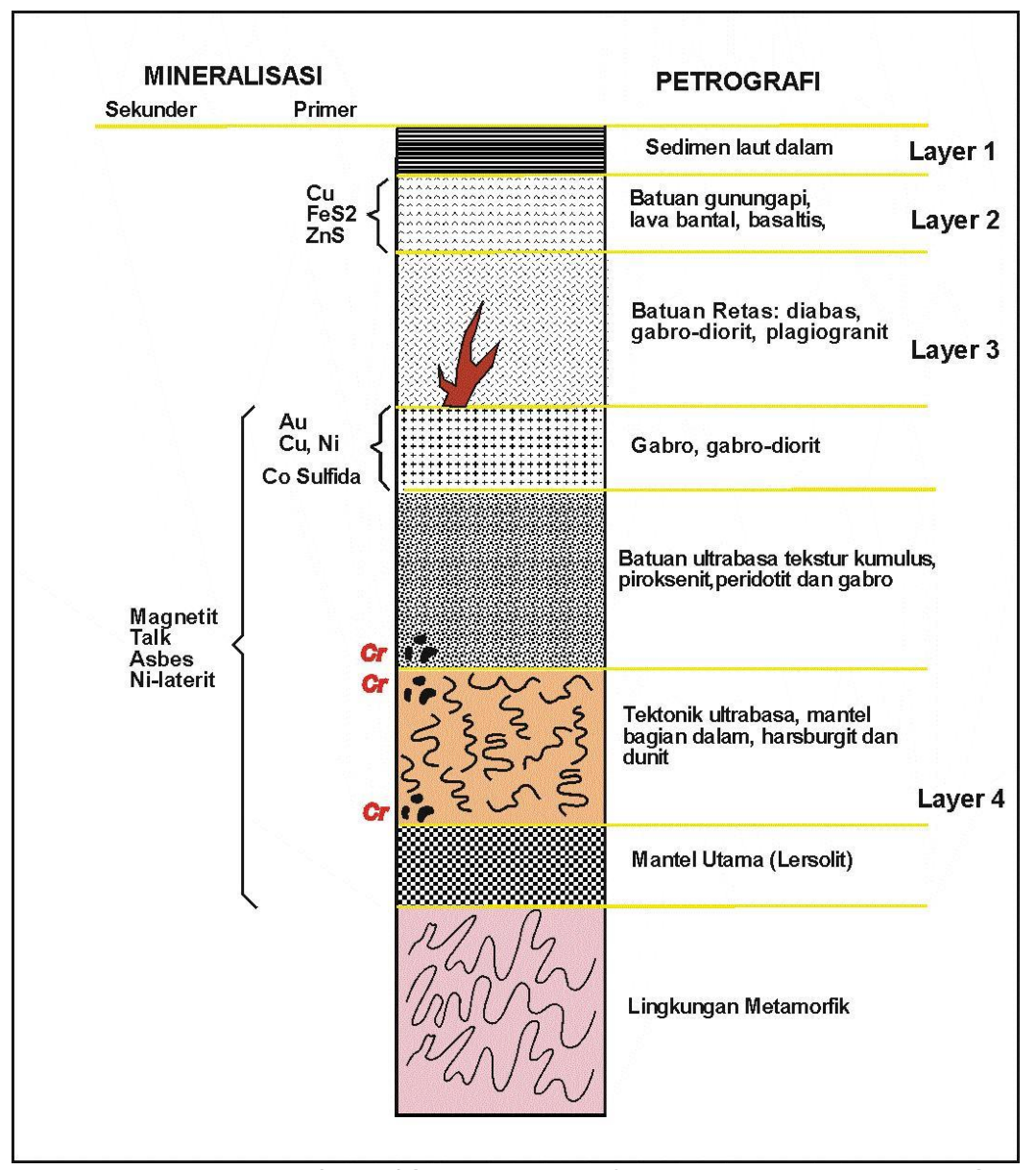

Gambar 15. Runtunan batuan ofiolit (Geoscience \& Natural Resources, Germany, 1982).

\section{Proses mineralisasi}

Proses mineralisasi sekunder di daerah ini dimulai dengan pelapukan batuan ultramafik baik secara fisik maupun kimiawi. Proses pelapukan ini erat sekali hubungannya dengan keseimbangan dalam kerak bumi untuk menghasilkan material baru yang disebabkan oleh udara, air dan kehidupan.

Pelapukan fisik merupakan proses penghancuran batuan secara fisik menjadi komponen kecil yang disebabkan oleh energi seperti air, perubahan temperatur, aktifitas pendinginan, eksfoliasi dan abrasi. Di daerah Pulau Gag, pelapukan fisik ini terutama disebabkan oleh abrasi air laut (gelombang). Sebagai contoh, misalnya batupasir kuarsa berubah menjadi butiran pasir kuarsa tanpa berubah komposisinya.
Sebaliknya, pelapukan kimia yang disebutkan pula proses dekomposisi, merupakan proses pelapukan yang sedikit lebih rumit dibandingkan dengan pelapukan fisik. Dalam pelapukan fisik, tidak terjadi perubahan komposisi kimia sedangkan dalam pelapukan kimia terjadi perubahan komposisi kimia. Sebagai contoh, feldspar akan menjadi mineral baru berupa kaolin bahkan produk pelapukan kimia tidak menghasilkan bentuk yang jelas (garam yang dihancurkan di dalam air).

Pelapukan kimia melibatkan beberapa proses, seperti dissolusi, silisifikasi, karbonisasi, hidrasi dan oksidasi. Namun, yang paling umum terjadi dalam pelapukan kimia adalah oksidasi. Oksidasi ini terjadi karena adanya reaksi oksigen, ukuran partikel, komposisi mineral, iklim, tumbuhan dan hewan. Di samping itu, dalam mempercepat proses, terlibat pula 
agen-agen lain seperti air, karbon dioksida, udara dan asam atau "H+". Dalam proses pelapukan kimia, agenagen yang disebutkan di atas bisa mempercepat ataupun memperlambat proses. Kuarsa $\left(\mathrm{SiO}_{2}\right)$, sebagai contoh, akan memperlambat proses sebaliknya mineral seperti olivin ( $\mathrm{Fe}, \mathrm{Mg}, \mathrm{SiO}_{4}$ ) akan mempercepat proses. Iklim, kelembaban yang diikuti oleh cuaca panas akan mempercepat pelapukan kimiawi.

Nampaknya, laterit yang terjadi di daerah Pulau Gag termasuk proses pelapukan kimiawi (oksidasi yang kuat) di mana batuan asal yang kaya mineral (nikel) diganti menjadi konsentrasi mineral baru berupa endapan nikel sekunder (garnierit). Hal ini serupa dengan pembentukan oksida besi di Pulau Bangka di samping menghasilkan bijih timah sekunder (Abidin dan Rusmana,2003), proses pembentukan oksida besi dan Komplek ofiolit di Gunung Kukusan, Kalimantan (Abidin, 2001; Abidin dan Hakim, 2001). Proses ini dikontrol oleh kondisi oksida besi yang memungkinkan untuk terbentuk. Hadirnya oksida besi sebagai hematit, gutit, laterit, limonit dan juga nikel, tentunya berasosiasi dengan batuan asal yang mengandung mineral ferromagnesian (piroksen, hornblenda dan olivin). Batuan yang mengandung mineral seperti ini adalah batuan ultramafik (harzburgit atau serpentinit).

Di lapangan, hampir 2/3 daerah Pulau Gag ditutupi oleh batuan tersebut. Proses pelapukan kimia itu telah menghasilkan laterit yang terdiri atas lapisan tanah penutup, lapisan limonit dan lapisan saprolit (Gambar 11 a, b). Lapisan tanah penutup merupakan soil dengan ketebalan berkisar antara 20-30 cm. Umumnya lapisan tanah penutup ini bercampur dengan akar-akar tumbuh-tumbuhan.
Lapisan limonit, yang berwarna merah kecoklatan mengandung oksida besi sekunder. Hasil pelapukan kedua berupa saprolit (lapisan di bawah lapisan limonit) yang juga berwarna merah kecoklatan, kaya akan lempung, dan masih memperlihatkan jejak tekstur maupun struktur batuan asal. Bijih nikel sekunder terdapat di dalam kedua lapisan ini namun konsentrasi nikel terdapat dalam lapisan saprolite ore (Gambar 11b). Pembentukan bijih nikel sekunder dalam kedua lapisan ini terjadi karena jejak nikel telah terdapat dalam batuan asal (ultramafik). Dalam proses lateritisasi dari batuan asal tersebut (dalam hal ini batuan ultramafik), nikel bersatu dengan air tanah dan secara kimiawi diendapkan kembali ke dalam zona oksida besi sebagai mineral garnierit (Gambar 16a, b).

Hasil analisis 6 penampang terpilih dari singkapan (0 m s.d. $7 \mathrm{~m}$ ) (Gambar 14) (Tabel 1) memperlihatkan bahwa kandungan $\mathrm{Ni}$ berkisar dari $1.15 \%$ s.d. $2.62 \%$ (limonit dan saprolit). Kandungan $\mathrm{Ni}$ ini ternyata sebagian besar terdapat dalam lapisan limonit $(0 \mathrm{~m}$ s.d. $4 \mathrm{~m})$ pada penampang No. 20; kedalaman (0 m s.d. 3 m) pada penampang No. 25; kedalaman (0 $\mathrm{m}$ s.d. $5 \mathrm{~m}$ ) pada penampang No. 0, 5 , 15; kedalaman $0 \mathrm{~m}$ s.d. $6 \mathrm{~m}$ dalam penampang No. 10. Secara keseluruhan kandungan $\mathrm{Ni}$ dalam lapisan limonit berkisar dari $1.15 \%$ s.d. $1.86 \%$. (Tabel 1 ). Lapisan saprolit ditemukan pada penampang No. 10 mulai kedalaman 6 meter, penampamg No. 5 dan No. 15 pada kedalaman mulai $5 \mathrm{~m}$, penampang No. 20 pada kedalaman mulai $4 \mathrm{~m}$ dan penampang No. 25 pada kedalaman mulai $3 \mathrm{~m}$. Kandungan Ni dalam lapisan saprolit ini berkisar dari $1.50 \%$ s.d. $2.62 \%$ (Tabel 1). Kombinasi nilai Ni baik dalam lapisan limonit dan lapisan saprolit maka nilai ratarata $\mathrm{Ni}$ sekitar $1.55 \%$. 


\section{MAKALAH ILMIAH}

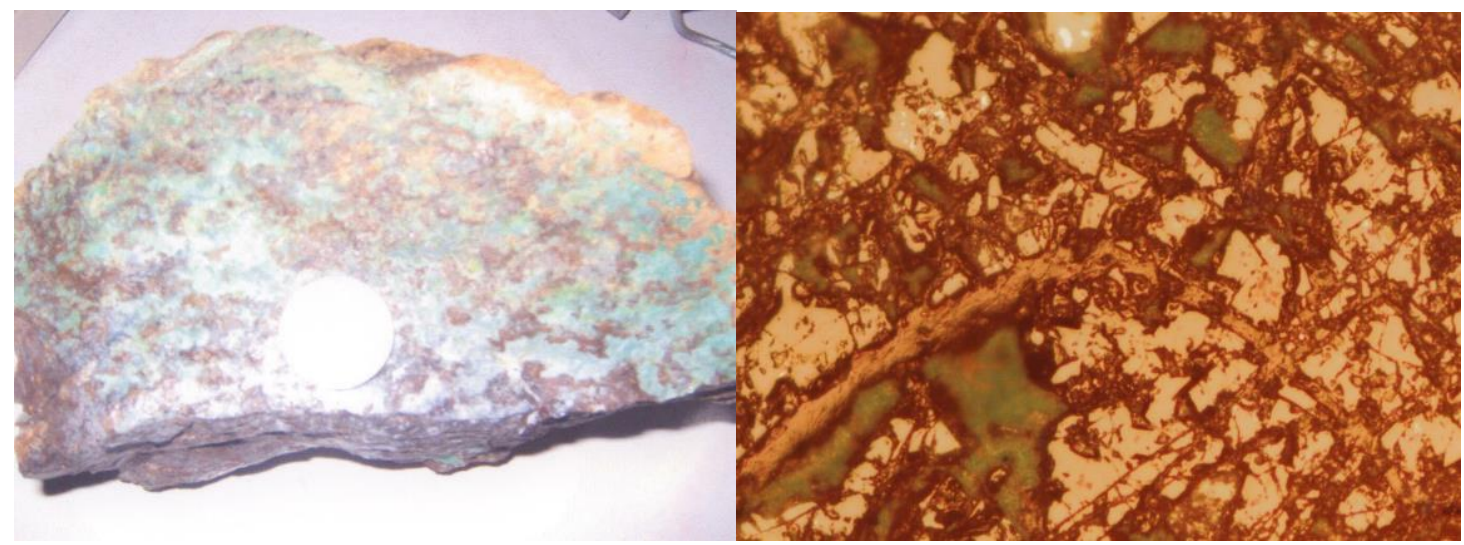

(a)

(b)

Gambar 16. Contoh terpilih dari mineral garnierit (a) dan poles garinierit (b)

Klasifikasi besaran sumberdaya mengacu pada JORC - Code sebagaimana dilaporkan per Juni 2007 menunjukkan bijih nikel didaerah ini mempunyai sumberdaya terukur 9.000 .000 ton; tertunjuk 56.000.000 ton dan tereka 208.000.000 ton (Anonim, 2007).

\section{KESIMPULAN}

Nikel laterit berupa garnierit di Pulau Gag ini terdapat dalam Komplek ofiolit yang berumur Jura. Proses pelapukan kimia batuan ofiolit/ultramafik membentuk laterit yang terdiri atas lapisan limonit dan lapisan saprolit. Bijih nikel sekunder terdapat di dalam kedua lapisan ini namun konsentrasi ekonomis dijumpai dalam lapisan saprolite ore. Dalam lapisan limonit dan saprolit, kandungan Ni masingmasing berkisar antara $1,15 \%$ s.d. $1,86 \%$ dan 1,50 s.d. $2,62 \%$. Total sumberdaya oksida dan silikat pada nikel laterit 237.000.000 ton.

\section{UCAPAN TERIMA KASIH}

Penulis mengucapkan terima kasih kepada Kepala Pusat Survei Geologi yang telah memberi kesempatan untuk melakukan peninjauan di Pulau Gag. Terima kasih sebesar-besarnya kepada PT. Gag Nikel dan PT. Antam-BHP (Ternate dan Gebe) yang telah telah memberikan banyak bantuan (akomodasi, transportasi dan data) juga Kepala Desa
Gambir yang telah memberi banyak kemudahan di pulau tersebut.

\section{DAFTAR PUSTAKA}

Anonim, 1999., Gag Island Joint Ventures Progress Repor \#1, PT. Antam BHP Minerals.

Anonim, 2007., Laporan akhir eksplorasi PT. Gag Nikel.

Abidin, H.Z., Wahyono, Ari, K. dan Amir, H., 2012. Eksplorasi nikel laterit di Pulau

Waigeo, Papua Barat. Laporan Perusahaan. Tidak terbit.

Abidin. H.Z. dan Rahman, 2011. Eksplorasi nikel laterit di daerah Baula, Kolaka, Sulawesi Tenggara. Laporan Perusahaan. Tidak terbit.

Abidin, H.Z. dan Baharuddin, 2007. Eksplorasi nikel laterit di daerah Maba,

Halmahera Timur, Maluku Utara. Laporan PT. KSM. Tidak terbit.

Abidin H.Z., Baharuddin dan Partoyo, E., 2007. Eksplorasi nikel laterit di daerah Buli, Haltim. Laporan PT.KSM. Tidak terbit.

Abidin, H.Z. dan Rusmana, E., 2003. Origin of iron oxide within weathered granite and tin alluvial deposition, South Bangka District, BangkaBelitung. Majalah Geologi Indonesia, 18 (2), 95-105.

Abidin, H.Z., 2001. Iron oxide associated with the ultramaphic rocks, Mt. Kukusan Area, South Kalimantan 


\section{MAKALAH ILMIAH}

Indonesian Mining Journal, 7 (3): 1423.

Abidin, H.Z. dan Hakim, AS., 2001. Dismembered ophiolite Complex in Mt. Kukusan Area, Batuicin District, South Kalimantan: Synthetic, origin and.

economic important. Publikasi Khusus, Puslitbang Geologi, 28: 75-88.

Edward, P. dan Atkinson, K (1986), Ore Deposit Geology, Chapman and Hill, London-Newyork, halaman 18-37.

Evan, A.M. (1992), Ore Geology and Industrial Minerals: An Introduction, Blackwell Scientific Publication, 390 h. Geoscience and Natural Resources, Germany, 1982.

Hamilton, W. (1979), Tectonic of the Indonesia Region, Geol.Survey Prof. Paper 1078, 345h
Kertapati, E., Asdani, I. Effendi (2001), Peta Kegempaan Indonesia, Pusat Penelitian dan Pengembangan Geologi, Bandung.

Nicholas, A. (1989). Structures of ophiolites and dynamics of oceanic lithosphere. Kluer Academic Publishers. Dordrecht-BostonLondon. 311h.

Pieters, P., C.J. Pigram, D.S. Trail, D.B. Dow (1983), The Stratigraphy of Western Irian Jaya, Bull. Geol. Res. and Dev. Centre, No.8 14-48.

Supriatna, S., Hakim A.S. dan Apandi, T. (1995), Peta Geologi Lembar Waigeo, Irian Jaya, Pusat Penelitian dan Pengembangan Geologi, Bandung.

Wilson, M. (1989), Igneous Petrogenesis, Unwin Hyman, London, 466 h.

$\begin{array}{ll}\text { Diterima } & : 4 \text { Mei } 2017 \\ \text { Direvisi } & : 15 \text { Mei } 2017 \\ \text { Disetujui } & : 31 \text { Mei } 2017\end{array}$

